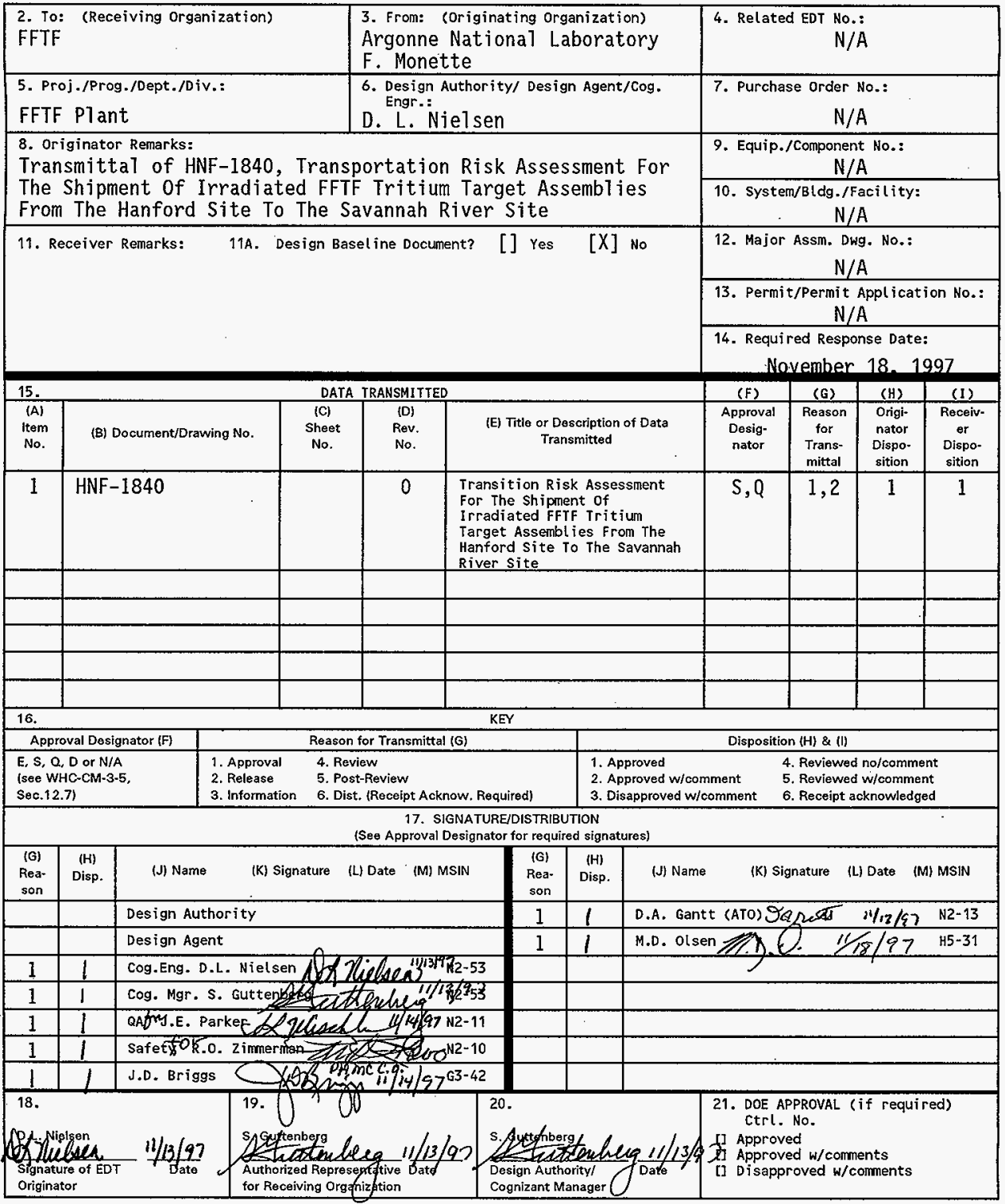




\section{Transportation Risk Assessment For The Shipment Of Irradiated FFTF Tritium Target Assemblies From The Hanford Site To The Savannah River Site}

F. Monette

Argonne Nationa] Laboratory, Argonne, IL

D. L. Nielsen

B \& W Hanford Company, Richland, WA 99352

U.S. Department of Energy Contract DE-AC06-96RL13200

$\begin{array}{lll}\text { EDT/ECN: } & 619611 & \text { UC: } 513 \\ \text { Org Code: } & 18200 & \text { Charge Code: } \\ \text { B\&R Code: } & \text { EX70026000 } & \text { Total Pages: } 26\end{array}$

Key Words: Transportation, Risk Assessment, Shipment, FFTF, Irradiated, Tritium, Tritium Target Assemblies, Savannah River

Abstract: A Draft Technical Information Document (HNF-1855) is being prepared to evaluate proposed interim tritium and medical isotope production at the Fast Flux Test Facility (FFTF). This report examines the potential health and safety impacts associated with transportation of irradiated tritium targets from FFTF to the Savannah River Site for processing at the Tritium Extraction Facility. Potential risks to workers and members of the public during normal transportation and accident conditions are assessed.

TRADEMARK DISCLAIMER. Reference herein to any specific commercial product, process, or service by trade name, trademark, manufacturer, or otherwise, does not necessarily constitute or imply its endorsement, recommendation, or favoring by the United States Government or any agency thereof or its contractors or subcontractors.

Printed in the United States of America. To obtain copies of this document, contact: Document Control services, P.0. $80 \times$ 950, Mailstop H6-08, Richland WA 99352, Phone (509) 372-2420; Fax (509) 376-4989.
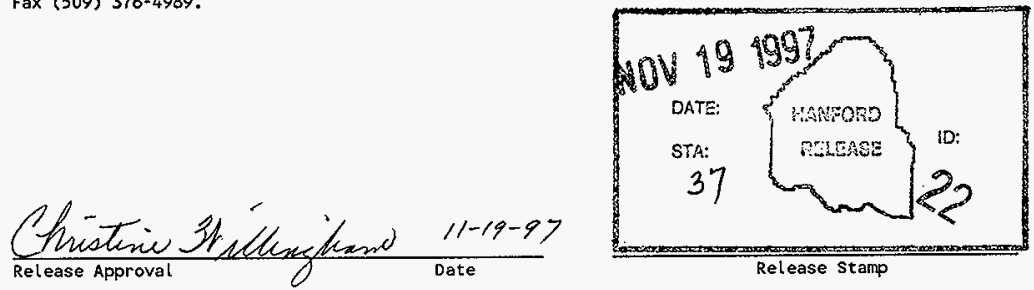

\section{Approved for Public Release}


HNF-1840, Rev. 0

TRANSPORTATION RISK ASSESSMENT FOR THE SHIPMENT OF IRRADIATED FFTF TRITIUM TARGET ASSEMBLIES FROM THE HANFORD SITE TO THE SAVANNAH RIVER SITE

November 10,1997

Environmental Assessment Division

Argonne National Laboratory

Argonne, IL

DOES NOT CONTAN CLASSIFIED OR

UVALASSIFED CONTROLLED

NUE TR INORMATION

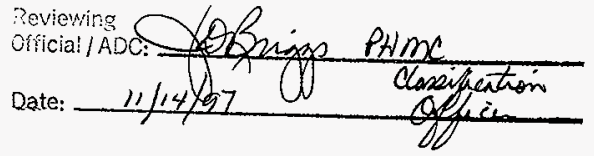


HNF-1840, Rev. 0

\section{TRANSPORTATION RISK ASSESSMENT FOR THE SHIPMENT OF IRRADIATED \\ FFTF TRITIUM TARGET ASSEMBLIES FROM THE HANFORD SITE TO THE SAVANNAH RIVER SITE}

\section{INTRODUCTION}

Production of tritium using the Fast Flux Test Facility (FFTF) would require the shipment of irradiated tritium target pins from FFTF to the Savannah River Site (SRS) for processing at the Tritium Extraction Facility (TEF). This report presents quantitative estimates of the human health risks posed by such shipments, including a discussion of the analytical methods and key assumptions employed in the assessment. Potential risks to workers and members of the public during normal transport and accident conditions are assessed. The scope of this transportation risk assessment is limited to the shipment of irradiated tritium targets from FFTF to SRS. Shipments of unirradiated targets and fresh nuclear fuel from manufacturers to the FFTF, and shipments of waste material and spent nuclear fuel from FFTF to storage or disposal facilities are not addressed.

During the operational period, several shipments containing irradiated targets would occur each year. The targets would be packaged in robust, Type-B shipping casks licensed by the U.S. Nuclear Regulatory Commission (NRC). These shipping casks must meet stringent federal standards (10 CFR 71) and are designed and constructed to contain their contents during both normal transport and during postulated transportation accidents. Casks potentially could be shipped by either truck or rail. All transportation activities - including shipment documentation, manifesting, placarding, and labeling - would be conducted in a manner consistent with Department of Transportation (DOT) regulations (49 CFR Parts 100-199). These regulations are designed to ensure that the transportation of radioactive materials is done safely. Although all transportation operations would be conducted in accordance with applicable regulations, potential risks to human health are associated with both normal transportation conditions and accidents.

During normal operations, workers and members of the public can be exposed to a low-level radiation field (generally gamma radiation) in the vicinity of a loaded shipping cask. This field, which is limited to low levels by Federal regulations (10 CFR 71), exists because the irradiated tritium targets emit penetrating radiation (gamma radiation) that is reduced, but not eliminated, by the shielding contained in the shipping cask. The radiation field around a cask decreases with the distance from the cask. The total radiation exposure of workers and the public depends on the strength of the radiation field, the distance from the cask, and the number and duration of exposures. Workers and members of the public living along a route, sharing the route, or at stops along the route, could receive small doses of radiation during each shipment.

During accident conditions, potential exposures to radiation can occur if the shipping cask is damaged such that the shielding is reduced or radioactive material is released from the cask to the environment. The NRC has estimated that certified Type B casks will survive approximately $99.4 \%$ of truck and rail accidents without releasing any of their contents (Fischer et al. 1987). 
Nevertheless, there is a possibility that radioactive material will be released to the environment under extremely severe accident conditions. The radioactive material released could be dispersed by the wind, potentially exposing members of the public through inhalation, direct radiation, and possible ingestion. The probability of an accident occurring depends on the total number of shipments, the distance traveled, and the accident rates along the shipment route. The risk associated with an accident depends on whether or not a release occurs, the location of the accident (whether it is in a rural, suburban, or urban area), the weather conditions at the time of the accident, and the type and amount of radioactive material released to the environment.

Risks are also associated with the operation of the transport vehicles themselves (i.e., trucks and trains); unrelated to the radioactive nature of the cargo. These risks, commonly called "vehiclerelated" or "nonradiological" risks, include the potential health impacts from exposure to vehicle exhaust emissions and the risks from transportation accidents that result in traffic fatalities from the physical forces of the accident.

The following sections describe the tritium targets, the shipment scenarios considered, the technical assessment approach, the major assessment assumptions, and the assessment results.

\section{TARGET CHARACTERISTICS AND SHIPMENT SCENARIOS}

The reference tritium target assembly is assumed to consist of 19 target pins bound together in a hexagonal arrangement. The target pins each have a diameter of 0.938 inches and contain solid lithium aluminate pellets encased within stainless steel cladding. A nickel coated Zircaloy getter surrounds the lithium pellets. The tritium produced by irradiation is contained within the lithium aluminate and getter material. In addition to tritium, irradiation results in the formation of a variety of activated metals in the stainless steel target cladding. Because these activation products are produced within the metal, they are unlikely to be available for release in an accident, although they will contribute to the external gamma dose rate in the vicinity of irradiated targets.

Following irradiation, the tritium targets would be packaged in Type B casks and shipped by truck or rail from FFTF to SRS. Shipments of the irradiated targets could consist of either intact assemblies or consolidated pins (i.e., disassembling the target assemblies and repackaging the individual pins). Because the exact shipment configuration is uncertain at this time, two credible shipment scenarios, defined based on existing FFTF infrastructure and Tritium Extraction Facility interface requirements (Nielsen 1997), have been evaluated in this report:

- Scenario 1. Shipments would consist of consolidated pins in a "close-packed" arrangement. As an upper bound, this loading configuration would consist of 361 pins per shipment (equivalent to 19 intact target assemblies). It is assumed that a maximum of 77 target assemblies (19 pins per target) would be disassembled and the pins shipped each year, resulting in an annual total of 4 cask shipments. Based on a design production goal of 2.89 
grams of tritium per pin and a specific activity for tritium of $9.64 \times 10^{3} \mathrm{Ci} / \mathrm{g}$, the total activity of tritium would be about $10 \times 10^{6} \mathrm{Ci}$ per shipment.

- Scenario 2. For scenario 2, shipments were assumed to consist of 80 pins in a close-packed arrangement. Because each shipment would contain fewer pins than defined for scenario 1 , this loading configuration would require approximately 18 cask shipments each year, with a total tritium activity of about $2 \times 10^{6} \mathrm{Ci}$ per shipment.

From a risk perspective, two differences between the scenarios are important to note. First, the two scenarios differ in the annual number of shipments, requiring 4 and 18 cask shipments per year for scenarios 1 and 2, respectively. Over a given route, the probability of an accident occurring increases proportionally with the number of shipments (i.e., the probability of an accident occurring is 4.5 times greater $(18 \div 4)$ for scenario 2 than scenario 1$)$. Second, the two scenarios differ in the total inventory of tritium per shipment, with scenario 1 having five times the amount of tritium per shipment than scenario 2 . Consequently, the amount of tritium potentially released in an accident is 5 times greater for scenario 1 than scenario 2 . Thus, although the probability of an accident is smaller for scenario 1, the potential consequences, if an accident occurred, are greater. Because the quantification of accident risk takes into account both the probability and consequence of accident occurrences, the differences between the two scenarios tend to balance one another, resulting in similar overall accident risks.

It was assumed for the purposes of this risk assessment that a Type B cask was available for both scenarios 1 and 2 and that the cask was capable of being shipped by either legal weight truck or rail. Note that because all Type B casks are designed to meet the same performance criteria, the results of the risk assessment depend only on the capacity of a cask and not on the characteristics of the specific cask used.

\section{RISK ASSESSMENT METHODOLOGY}

The transportation risk assessment is used to estimate the reasonably foreseeable risks to workers and members of the public for both routine and accident conditions. In terms of specific receptors, risks are estimated for the entire population of potentially exposed people, as well as for maximally exposed individuals. As introduced above, during the normal or routine transportation of radioactive materials, radiological risks are caused by exposure to external penetrating radiation in the vicinity of loaded shipments. (For the majority of DOE radioactive material shipments, external exposure rates are limited by Federal regulations to a maximum value of $10 \mathrm{mrem} / \mathrm{h}$ measured $2 \mathrm{~m}$ from the lateral surfaces of the transport vehicle.) The radiological risks from transportation accidents result from the potential release and dispersal of radioactive material to the environment.

The technical approach for conducting the transportation risk assessment is shown in Figure 1. Note: all tables and figures are placed at the end of the text.) The approach used is identical to that used in several recent DOE NEPA assessments, including the INEL Programmatic Spent 
Nuclear Fuel Management EIS (DOE 1995), the DOE NonProliferation Policy Concerning Foreign Research Reactor Spent Nuclear Fuel EIS (DOE 1996), and the Programmatic Waste Management EIS (DOE 1997). The approach utilizes the RADTRAN 4 computer code (Neuhauser and Kanipe 1992) to estimate the collective population risk during routine and accident transportation conditions. The collective population risk is a measure of the total radiological risk posed to society as a whole by the shipments being considered. As such, the collective population risk is used as the primary means of comparison among different shipments or alternatives. In addition to collective population risks, supplemental analyses are conducted using the RISKIND computer code (Yuan et al. 1995) to address areas of specific concern to individuals or population subgroups. RISKIND is used for estimating routine doses to maximally exposed individuals and for assessing the consequences of the most severe credible transportation accidents. The supplemental analyses are primarily meant to address "what if" questions, such as, "what if I live next to a site access road?" or "what if an accident happens near my town?"

The RADTRAN 4 computer code was developed by Sandia National Laboratories to calculate the collective population risks associated with the transportation of radioactive materials by a variety of modes, including truck, rail, air, ship, and barge. The code has been extensively reviewed, updated, and verified since it was issued in the late 1970s, and the latest version is available for use by DOE and its contractors through the TRANSNET computer network.

The RADTRAN 4 risk calculations for routine transportation include models describing (1) collective doses to persons living or working adjacent to the transport route, (2) collective doses to persons sharing the transport route, (3) collective doses to persons at stops (e.g., refueling stops or rail classification yards), and (4) collective doses to transportation crew members. The doses calculated by using the first three models are added together to yield the collective risk to the public; the dose calculated by using the fourth model represents the collective risk to workers. The RADTRAN routine dose models are not intended to be used for estimating specific risks to individuals.

Accident occurrences are statistical in nature; therefore, accident risk is commonly defined as the product of the accident consequence (dose) and the probability of the accident occurrence. In this respect, the RADTRAN code estimates the collective accident risk to populations by considering a spectrum of credible transportation accidents. The accident spectrum is designed to encompass the range of all possible accident environments, including low probability accidents that have high consequences, and high probability accidents that have low consequences. Accident frequencies are generally derived from historical records for the transport mode being considered. The calculation of collective accident risk employs models that quantify the range of potential accident severities, the package response to a particular accident environment, and the exposure of populations following the dispersion and transport of released radioactive material into the environment. The exposure pathways include external exposure to the passing radioactive cloud as well as from contaminated ground, and internal exposure from inhalation of airborne contaminants and ingestion of contaminated food. The collective accident risk results can be directly compared to the routine population risks because they incorporate the probability of accident occurrences. 
The RISKIND computer code was developed for the DOE Office of Civilian Radioactive Waste Management for the specific purpose of analyzing the exposures of individuals during the routine transportation of spent nuclear fuel. In addition, the RISKIND code is designed to allow a detailed assessment of the consequences to individuals and population subgroups from accidents involving shipments of other radioactive materials under various environmental settings.

RISKIND is used to address "what if" questions in two areas. First, RISKIND is used to calculate the dose to maximally exposed individuals for a number of hypothetical exposure scenarios during routine conditions. Second, RISKIND is also used to provide a detailed assessment of the consequences of the most severe transportation accidents. Whereas the RADTRAN accident risk assessment considers the entire range of accident severities and their related probabilities, the accident consequence assessment assumes that an accident of the highest credible severity has occurred. These accidents represent low probability, high consequence events. The actual probability of accidents of this magnitude occurring depends on the total shipment distance for each alternative; however, accidents of this severity are extremely rare in general. Detailed consequence calculations are performed using RISKIND for accidents occurring in rural, suburban, and urban population density zones. The exposure pathways considered are similar to those discussed above for RADTRAN. Accident consequences are assessed for local populations as well as maximally exposed individuals for various meteorological conditions.

Nonradiological impacts are also estimated for both routine and accident conditions. The nonradiological impacts during routine conditions are associated with exposure to vehicle exhaust emissions, and are calculated based on the total route mileage in urban areas and health risk factors provided in Rao (1982). The nonradiological impacts from accidents are defined as fatalities caused by accident occurrences, unrelated to the radioactive cargo. The number of traffic-accident fatalities are estimated by multiplying the total round-trip shipment distance by the appropriate accident fatality rates, which are based on DOT statistics. State-level accident data are utilized in this assessment.

\section{PARAMETERS AND ASSUMPTIONS}

The RADTRAN and RISKIND computer codes require that a number of parameters be specified. These parameters describe such factors as the radiological inventory, package characteristics, route and mode characteristics, and the package response in accident environments. In general, the best available data specific to the FFTF target shipments have been used in the risk assessment models. However, in certain cases FFTF target specific data are unavailable or highly uncertain at this time. Consequently, conservative assumptions have been made for purposes of the risk assessment. These conservative assumptions are intended to over-estimate the actual risks that would be incurred during shipments of the tritium targets. Similar parameters and assumptions have been used in the RADTRAN and RISKIND models. The major input parameters and assumptions used in the risk assessment are discussed below. 
Shipment Radiological Inventory. The assessment of accident risk depends on the radiological inventory, defined as the type and quantity of radionuclides that could be released and dispersed during an accident. For shipments of irradiated tritium targets, the radionuclide of concern is tritium (H-3); no other volatile radionuclides are expected to be produced in the targets (Nielsen 1997). The total shipment inventories of tritium are equal to $10 \times 10^{6} \mathrm{Ci}$ per shipment for scenario 1 , and $2 \times$ $10^{6} \mathrm{Ci}$ per shipment for scenario 2 .

Although a variety of activated metals are induced in the target cladding and getter, these elements are unilikely to be available for release in an accident (Nielsen 1997). The potential release of activated metals was considered in the accident assessment; however, activated metals were found to contribute a negligible radiation dose compared to tritium (i.e., less than $0.1 \%$ of the total dose) following a release.

Packaging/Shipment Configuration. All transportation activities must take place in accordance with the applicable regulations of the U.S. Department of Transportation (DOT) and U.S. Nuclear Regulatory Commission (NRC) (Code of Federal Regulations [CFR] Title 10, Part 71, and Title 49, Part 173 ). Shipments of irradiated tritium targets would take place in Type B casks, which must provide a high degree of assurance that even in severe accidents the integrity of the package will be maintained with essentially no loss of the radioactive contents or serious impairment of the shielding capability. Irradiated tritium targets were assumed to take place by exclusive-use trucks or by general freight trains, with one cask per truck or railcar. Because a specific Type B cask has not yet been identified, a generic cylindrical cask $3 \mathrm{~m}$ in length was assumed for assessment purposes (RADTRAN uses a 1-dimensional line source model for dose calculations based on the largest package dimension).

External Cask Dose Rate. The risk during routine transport conditions depends on the external dose rate in the vicinity of a loaded shipment. For exclusive-use shipments, the maximum external dose rate is limited by federal regulations to a value of $10 \mathrm{mrem} / \mathrm{h}$ measured at $2 \mathrm{~m}$ from the lateral surfaces of the conveyance. The actual dose rate will be a function of the composition and configuration of shielding and containment materials used in the packaging, the geometry of the loaded shipments, and characteristics of the targets. Because the specific cask to be used for shipments and the dose rate from irradiated targets are uncertain at this time, the cask external dose rate was conservatively assumed to be equal to the regulatory limit (i.e., $10 \mathrm{mrem} / \mathrm{h}$ at $2 \mathrm{~m}$ ) for both scenarios 1 and 2 .

Shipment Route/Population Data. The DOT's public highway routing regulations are prescribed in 49 CFR 177 (Docket HM-164a). The regulation's objectives are to reduce the impacts of transporting radioactive materials, to establish consistent and uniform requirements for route selection, and to identify the role of state and local governments in the routing of radioactive materials. The regulations attempt to reduce potential hazards by avoiding populous areas and by minimizing travel times. Further, they require that the carrier of radioactive materials ensure that the vehicle is operated on routes that minimize radiological risks, that accident rates, transit times, population density and activity, time of day, and day of week are considered in determining risk. 
A shipment of a "highway route controlled quantity" of radioactive materials is required by Docket HM-164 to use the interstate highway system except when moving from origin to interstate or from interstate to destination, when making necessary repair or rest stops, or when emergency conditions make continued use of the interstate unsafe or impossible. Carriers are required to use interstate circumferential or bypass routes, if available, to avoid populous areas. Other "preferred highways" may be designated by any state or Indian tribe to replace or supplement the interstate system. Under its authority to regulate interstate transportation safety, the DOT can prohibit state and local bans and restrictions as "undue restraint of interstate commerce." State or local bans will be preempted if inconsistent with Docket HM-164. Similar routing requirements do not exist for rail transportation.

For the risk assessment, representative highway and rail routes from the Hanford Site to SRS were generated and analyzed by using the routing models HIGHWAY (Johnson et al. 1993a) and INTERLINE (Johnson et al. 1993b), respectively. Both routing models were developed by Oak Ridge National Laboratory. These routing models are updated periodically to reflect current road and track conditions and have been bench-marked against the reported shipment distances and observations of commercial firms. The Hanford to SRS route information, including distance and fractions of travel in urban, suburban, and rural population zones, is provided in Table 1 for truck shipments and Table 2 for rail shipments. Route-specific population data was used in the risk assessment. The routes calculated conform to current routing practices and all applicable routing regulations and guidelines, but do not necessarily represent the actual route that will be used in the future.

For the accident consequence assessment, average population densities were used for accidents in rural, suburban, and urban areas. The populations densities used were 7; 800; and 1,900 persons $/ \mathrm{km}^{2}$ for rural, suburban, and urban areas, respectively.

Accident Rates. For the calculation of accident risks, state-specific accident rates were taken from data provided in Saricks and Kvitek (1994). State-specific truck accident rates were based on statistics compiled by the DOT Office of Motor Carriers for the period 1986 through 1988. For highway shipments, the accident rates were computed specifically for heavy-combination trucks involved in interstate commerce and separate accident rates were used for rural, suburban, and urban population density zones in each state. A summary of the accident occurrence and fatality statistics for the states traversed by the shipment routes is provided in Table 3 .

Accident Severity and Cask Release Characteristics. Accident risks are typically calculated by describing the expected release from a cask as a function of the severity of the accident. Accident severity ranges from relatively minor accidents, for which no release would be expected, to extremely severe accidents, for which a release of some magnitude could potentially occur. The amount released from a package in an accident depends on characteristics of both the package and the material within the package. 
For Type B casks, the range of all potential transportation accident severities has been described in a U.S. Nuclear Regulatory Commission (NRC) report called the Modal Study (Fischer 1987). The Modal Study was used as the basis for the accident risk assessments conducted for both the INEL Programmatic Spent Nuclear Fuel Management EIS (DOE 1995) and the DOE NonProliferation Policy Concerning Foreign Research Reactor Spent Nuclear Fuel EIS (1996). The Modal Study accident classification scheme categorizes accidents as a function of the magnitudes of the mechanical forces (impact) and thermal forces (fire) to which a package may be subjected. Twenty different accident response categories are defined, which are typically combined into six levels of accident severity for risk assessment purposes. A conditional probability is assigned to each category, with minor accidents being the most frequent and severe accidents the most rare. The accident severity scheme is designed to take into account all credible transportation accidents, including accidents with low probability but high consequences and those with high probability but low consequences. The Modal Study estimates that Type B casks will survive approximately 99.4\% of all truck and rail accidents without releasing any of the shipment contents. The remaining $0.6 \%$ of accidents would thus involve some level of release.

For each severity category, the Modal Study presents estimates of release fractions, defined as the fraction of the radioactive material in a package that could be released to the environment. However, the release fractions presented in the Modal Study are specific to spent nuclear fuel assemblies and are therefore not necessarily representative of tritium target assemblies. Consequently, a conservative and simplified approach was taken for this risk assessment based upon the expected performance of tritium targets under accident conditions.

The maximum release fraction for tritium from a damaged target assembly has been conservatively estimated to be approximately $0.8 \%$ (Nielsen 1997). Although it would be expected that the release fraction would be less for accidents of lesser severity, for this risk assessment it was assumed that if the accident severity was sufficient to result in a release from the cask (i.e., $0.6 \%$ of all accidents), then the maximum tritium release would occur. Therefore, two accident severity categories and corresponding release fractions were used in the assessment, as summarized in Tables 4 and 5. The tritium was assumed to be released as water vapor. The release fraction for activated metals was assumed to be $5 \times 10^{-8}$ (Neuhauser and Kanipe 1992).

Based on the release fraction for tritium presented in Table 4, the maximum release of tritium to the environment in severe accidents would be approximately $80,000 \mathrm{Ci}$ for scenario 1 and $16,000 \mathrm{Ci}$ for scenario 2.

Meteorological Conditions. Because it is impossible to predict the specific location of a transportation accident, generic meteorological conditions were selected for the risk (RADTRAN calculations) and consequence (RISKIND calculations) assessments. For the accident risk assessment, neutral weather conditions (Pasquill Stability Class D) and an average wind speed of $4 \mathrm{~m} / \mathrm{s}$ were assumed. Since neutral meteorological conditions comprise the most frequently occurring atmospheric stability condition in the United States, these conditions are most likely to be present in the event of an accident. For the accident consequence assessment, doses were 
assessed under both neutral (Class D) and stable (Class F) atmospheric conditions, with respective wind speeds of 4 and $1 \mathrm{~m} / \mathrm{s}$. Results calculated for neutral conditions are meant to represent the most likely consequences, and the results for stable conditions a "worst-case" weather situation.

Maximally Exposed Individual Exposure Scenarios. For routine transportation conditions, the risk to maximally exposed individuals has been estimated using RISKIND for a number of hypothetical exposure scenarios. The dose to each maximally exposed individual considered is calculated for a given distance, duration, and frequency of exposure specific to that receptor. The distances, durations, and frequencies of exposure are similar to those given in previous transportation assessments (DOE 1995, DOE 1996, DOE 1997). The exposure scenarios are not meant to be exhaustive but were selected to provide a realistic range of potential exposure situations. The exposure scenarios considered are the following: 
1. Crew Members (truck and rail). Crew members are assumed to be occupational radiation workers and would be monitored by a dosimetry program. Therefore, the maximum allowable dose would be $5 \mathrm{rem} / \mathrm{yr}$, although DOE maintains an administrative control level of $2 \mathrm{rem} / \mathrm{yr}$.

2. Inspectors (truck and rail). Inspectors are assumed to be either federal or state vehicle inspectors. Inspectors are not assumed to be monitored by a dosimetry program. An average exposure distance of $3 \mathrm{~m}$ and an exposure time of $30 \mathrm{~min}$ is assumed. No assumptions are made concerning the frequency of inspections.

3. Resident (truck and rail). A resident is assumed to live $30 \mathrm{~m}$ from a site entrance route. Shipments are assumed to pass at a velocity of $15 \mathrm{mph}$ and the resident is exposed unshielded. Cumulative doses are assessed based on the number of shipments entering or exiting the site and assuming the resident is present for 100 percent of the shipments.

4. Person in Traffic Obstruction (truck and rail). A person is assumed to be stopped next to a shipment (due to traffic, etc.). The person is assumed to be exposed unshielded at a distance of $1 \mathrm{~m}$ for a duration of $30 \mathrm{~min}$.

1. Person at a Truck Service Station (truck only). A person is assumed to be exposed at an average distance of $20 \mathrm{~m}$ for a duration of $2 \mathrm{~h}$. This receptor could be a worker at a truck stop.

1. Rail-Yard Crew Member. A rail-yard crew member is not assumed to be monitored by a dosimetry program. An average exposure distance of $10 \mathrm{~m}(32.8 \mathrm{ft})$ and an exposure duration of 2 hours are assumed.

1. Resident Near. $a$ Rail Stop. A resident is assumed to live near a rail classification yard. The resident is assumed to be exposed unshielded at a distance of $200 \mathrm{~m}(656 \mathrm{ft})$ for a duration of 20 hours.

The largest uncertainty in predicting the dose to maximally exposed individuals during transportation involves determining the frequency of exposure occurrences when multiple shipments take place over the course of the year. This difficulty results from the uncertainties in future shipment schedules, route selection, and the inherent uncertainty in predicting the frequency of random or chance events. For instance, it is conceivable that an individual may be stopped in traffic next to a shipment; however, it is difficult to predict how often the same individual would experience this event. Therefore, for the majority of receptors considered, doses are assessed on a per event basis. To account for possible multiple exposures, ranges of realistic total doses are discussed qualitatively. One exception is the calculation of the dose to a hypothetical resident living near a site entrance route. For these residents, total doses are calculated based on the number of shipments entering or exiting each site.

General RADTRAN Input Parameters. In addition to the specific parameters discussed above, values for a number of general parameters must be specified within the RADTRAN code. These general parameters define basic shipment and traffic characteristics and are specific to the mode of 
transportation. The RADTRAN code user's manual (Neuhauser and Kanipe 1992) contains derivations and descriptions of these parameters. The general RADTRAN input parameters used in the transportation risk assessment are summarized in Table 6.

Health Risk Conversion Factors. Health risk conversion factors are used to predict the expected number of human health effects following radiation exposure. The health risk conversion factors used to estimate expected cancer fatalities were derived from ICRP Publication 60 (ICRP 1991): $5.0 \times 10^{-4}$ and $4.0 \times 10^{-4}$ fatal cancer cases per person-rem for members of the public and workers, respectively. Cancer fatalities occur over the lifetimes of the exposed populations.

\section{ASSESSMENT RESULTS}

Transportation risks were calculated for the transportation of irradiated tritium targets from the Hanford Site to SRS using the methodology and assumptions presented above. Risks were evaluated for the following areas: (1) collective risks to workers and members of the public (RADTRAN), (2) risks to maximally exposed individuals during routine conditions (RISKIND), and (3) risks to populations and maximally exposed individuals if the maximum severity accident occurred (RISKIND). The assessment results are summarized for both shipment scenario 1 and scenario 2 in the following sections.

Shipment Summary. The annual number of shipments and one-way shipment mileage for truck and rail modes for both shipment scenarios are summarized in Table 7. Scenario 1 would require 4 cask shipments annually, covering approximately 10,900 one-way highway miles or 11,800 rail miles. Scenario 2 would require 18 cask shipments annually, covering approximately 49,100 oneway highway miles or 53,200 rail miles.

Collective Population Risk Results. The results of the collective population risk assessment are summarized in Table 6. The collective risk results are presented on an annual basis. The total impacts over the duration of the program can be found by multiplying the annual impacts by the anticipated program duration.

The total estimated number of fatalities from cargo-related (radiological) causes are much less than 1 latent cancer fatality from routine and accident conditions combined for both truck and rail shipment modes. For truck shipments, the total number of latent-cancer fatalities among the crew and public was estimated to be 0.001 per year for scenario 1 , and 0.005 per year for scenario 2. Radiological impacts are slightly lower for rail shipments. The difference in impacts between the two scenarios results directly from the assumption that the external dose rate is equal to the regulatory limit of $10 \mathrm{mrem} / \mathrm{hr}$ for all shipments. Table 7 also includes estimates of the impacts from vehicle-related (nonradiological) causes. The vehicle-related risks are generally similar to the cargo-related risks. 
Maximally Exposed Individual Assessment (Routine Conditions). The estimated doses during routine transportation conditions for each of the individual receptors considered are presented in Table 8 on a per-event basis. The total dose for repeated exposures can be estimated by multiplying the per-event dose by the number of exposure-causing events anticipated. All doses were estimated to be much less than levels that would be expected to result in doses to members of the public approaching the regulatory limit of $100 \mathrm{mrem} / \mathrm{yr}$.

The potential exists for significant individual exposures if multiple exposure-causing events occur. For instance, the dose to a person stuck in traffic next to a shipment for 30 minutes is estimated to be about 11 mrem. If the duration of exposure is longer, the dose would rise proportionally. Therefore, a person could conceivably receive a dose on the order of 10 to $20 \mathrm{mrem}$ while stopped in traffic next to a shipment. The potential for the same individual to be stopped in close proximity to more than one shipment is considered to be extremely low. The dose to a resident living $30 \mathrm{~m}$ from a route and witnesses every shipment pass would be much less than 1 mrem. For comparison, the average individual dose from background radiation in the United States is approximately $360 \mathrm{mrem} / \mathrm{yr}$.

Accident Consequence Assessment (Population and Maximally Exposed Individual). The consequences of the maximum severity accidents were estimated for rural, suburban, and urban populations under neutral and stable weather conditions. It was assumed that following the worst credible transportation accident, $0.8 \%$ of the tritium inventory would be released, corresponding to $80,000 \mathrm{Ci}$ of tritium for scenario 1 , and $16,000 \mathrm{Ci}$ of tritium for scenario 2 for both truck and rail shipments. Population doses were estimated for a uniform population density within an $80-\mathrm{km}$ (50mi) radius of the accident site. Doses to a maximally exposed individual located $100 \mathrm{~m}$ from the accident site were also estimated. The probability of such on accident was conservatively estimated to be approximately $2 \times 10^{-5}$ per year for scenario 1 , and $9 \times 10^{-5}$ per year for scenario 2 (the probability estimates are based on the total one-way distances traveled, the accident rates given in Table 2, and a conditional probability of the maximum release should an accident occur of 0.006 ).

The collective population consequences are summarized in Table 9 for scenarios 1 and 2 . For all accident locations and weather conditions, less than one latent cancer fatalities would be expected among the exposed populations following the maximum credible accident. Radiation doses would be greatest for urban accidents, and least for rural accidents. In addition, radiation doses would be greater under stable weather conditions than under more prevalent neutral conditions. For scenario 1 , the radiation dose to an individual $100 \mathrm{~m}$ from the accident site, assumed to be present for 2 hours as the plume passed, was estimated to be approximately 2 rem. during neutral weather conditions, and approximately 40 rem during stable conditions. For scenario 2 , the maximum doses would be approximately $0.4 \mathrm{rem}$ and $8 \mathrm{rem}$ for neutral and stable conditions, respectively. Such dose levels would not be expected to cause acute fatalities in the exposed individuals, but would result in an increased chance of a latent fatal cancer of between 0.0002 and 0.02 over the lifetimes of the individuals. 
Figure 1. General Transportation Risk Assessment Approach

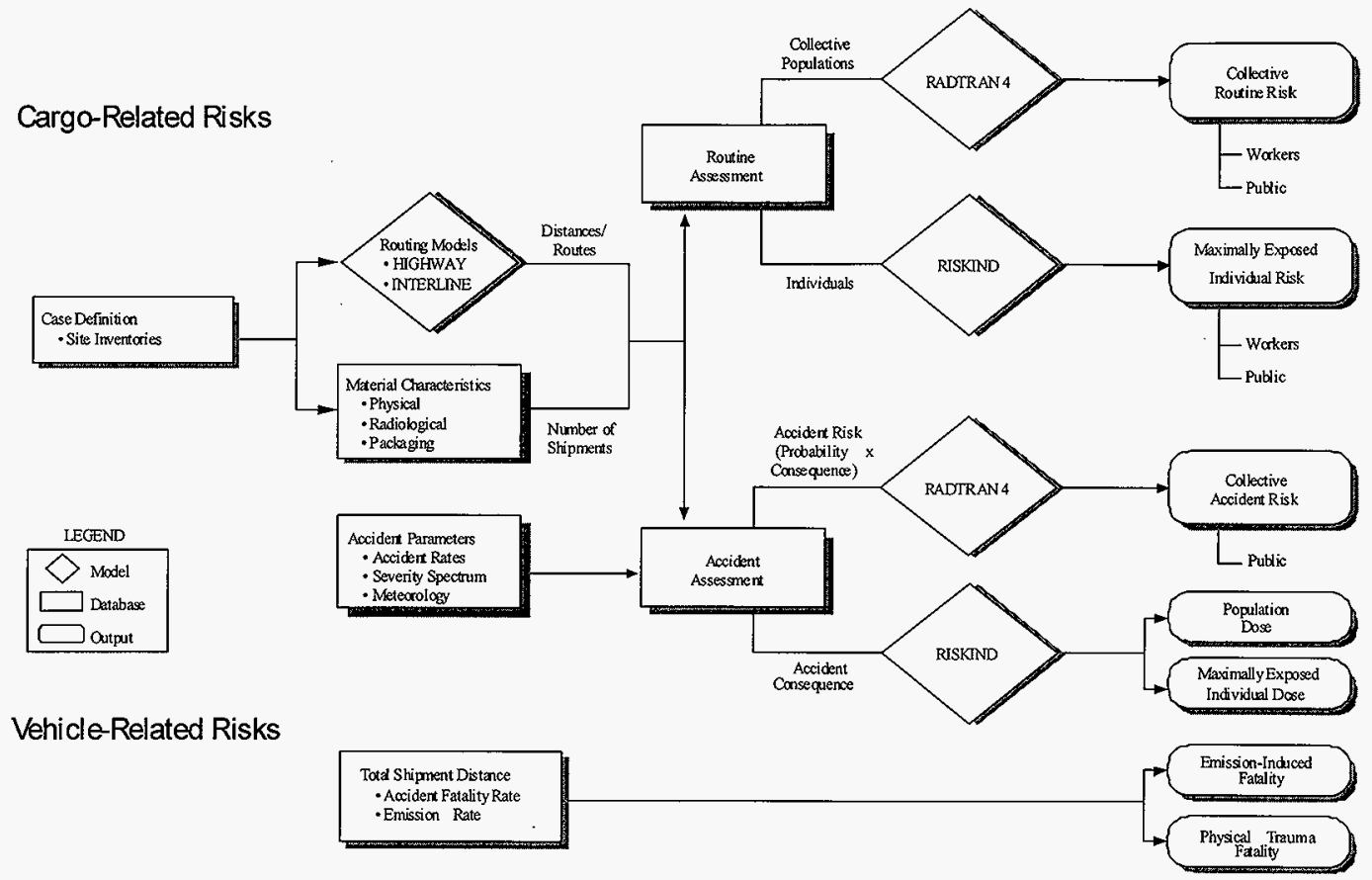

Page 14 
HNF-1840, Rev. 0

Table 1. Hanford to SRS highway route data. (source: HIGHWAY routing model [Johnson et al. 1993a])

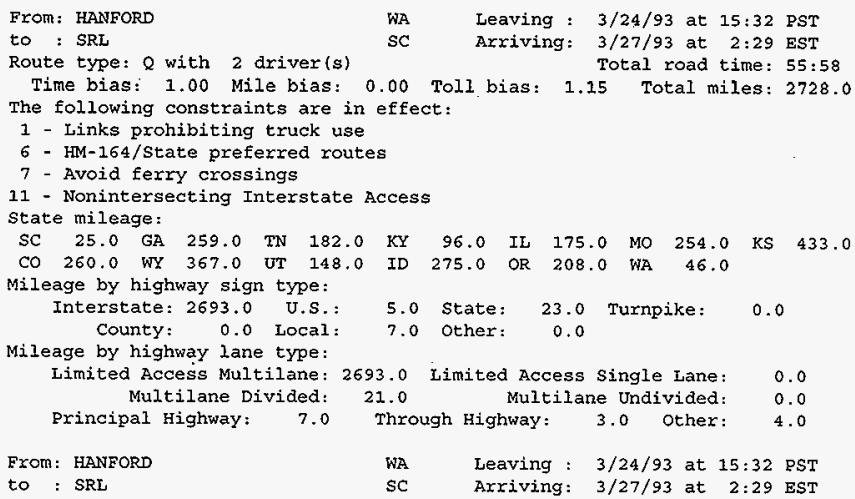

\begin{tabular}{|c|c|c|c|c|c|c|c|c|c|c|c|c|}
\hline \multicolumn{13}{|c|}{ Routing through: } \\
\hline 0.0 & & & HANEORD & & & & WA & 0.0 & $0: 00$ & $3 / 24$ & (2) & $15: 32$ \\
\hline 4.0 & LR4 S & & RICHLAND & $\mathrm{N}$ & $\$ 240$ & LR4S & WA & 4.0 & $0: 09$ & $3 / 24$ & (3) & $15: 41$ \\
\hline 7.0 & $\$ 240$ & & RICHLAND & SE & $\mathrm{I} 182$ & $\$ 240$ & WA & 11.0 & $0: 24$ & $3 / 24$ & (a) & $15: 56$ \\
\hline 5.0 & I182 & & WEST RICHLAND & $s$ & $I 182$ & I82 & WA & 16.0 & $0: 29$ & $3 / 24$ & (3) & $16: 01$ \\
\hline 41.0 & 182 & & HERMISTON & SW & I82 & I84 & $\mathrm{OR}$ & 57.0 & $1: 14$ & $3 / 24$ & (3) & $16: 46$ \\
\hline 512.0 & I84 & & TREMONTON & W & I15 & I84 & UT & 569.0 & $11: 32$ & $3 / 25$ & 3 & $4: 04$ \\
\hline 39.0 & $I 15$ & I 84 & OGDEN & $\mathbf{s}$ & I15 & I84 & UT & 608.0 & $12: 15$ & $3 / 25$ & (ब) & $4: 47$ \\
\hline 39.0 & I84 & & ECHO & & 180 & I84 & $\mathrm{UT}$ & 647.0 & $12: 57$ & $3 / 25$ & (2) & $5: 29$ \\
\hline 389.0 & I80 & & CHEYENNE & sw & 125 & I80 & WY & 1036.0 & $1: 02$ & $3 / 25$ & (9) & $13: 34$ \\
\hline 91.0 & I25 & & COMMERCE CITX & $\mathrm{w}$ & I 25 & 176 & co & 1127.0 & $23: 11$ & $3 / 25$ & (1) & $15: 43$ \\
\hline 1.0 & I76 & . & COMMERCE CITY & NW & 1270 & I76 & CO & 1128.0 & $23: 12$ & $3 / 25$ & @ & $15: 44$ \\
\hline 5.0 & 1270 & & DENVER & $\mathrm{NE}$ & 1270 & I70 & co & 133.0 & $23: 18$ & $3 / 25$ & (-) & $15: 49$ \\
\hline 525.0 & I70 & & TOREKA & $w$ & I 470 & I70 & $\mathrm{KS}$ & 1658.0 & $33: 50$ & $3 / 26$ & ( & $: 22$ \\
\hline 7.0 & $I 470$ & & TOPEKA & $s$ & 1335 & 1470 & ks & 665.0 & $3: 58$ & $3 / 26$ & (Q) & $: 29$ \\
\hline 5.0 & I470\$ & TKST\$ & TOPEKA & E & 1470 & 170 & KS & 1670.0 & $34: 03$ & $3 / 26$ & (1) & $3: 35$ \\
\hline 47.0 & I70 \$ & TKSTS & KANSAS CITY & W & I 435 & 170 & $\mathrm{KS}$ & 1717.0 & $4: 55$ & $3 / 26$ & Q & $4: 26$ \\
\hline 33.0 & 1435 & & KANSAS CITY & SE & I 435 & 170 & MO & 50.0 & $35: 31$ & $3 / 26$ & 0 & $5: 02$ \\
\hline 227.0 & 170 & & ST LOUIS & SW & I270 & $x 70$ & мO & 77.0 & 8 & $3 / 26$ & (3) & $10: 10$ \\
\hline 22.0 & 1270 & & EDWARDSVILLE & SW & I255 & 1270 & IL & 99.0 & 2 & $/ 26$ & Q & $10: 33$ \\
\hline 11.0 & I255 & & WASHINGTON PK & $S E$ & I255 & $\mathrm{I} 64$ & IL & 10.0 & 14 & $/ 26$ & $\theta$ & $10: 45$ \\
\hline 64.0 & I64 & & MT VERNON & NW & 157 & I64 & IL & 74.0 & 24 & $/ 26$ & (ब) & $11: 55$ \\
\hline 5.0 & I57 & 164 & MT VERNON & SW & I57 & $\mathrm{I} 64$ & IL & 79.0 & 30 & $3 / 26$ & (9) & $12: 01$ \\
\hline 48.0 & 157 & & PULLEYS MILL & $\mathrm{W}$ & $I 24$ & I57 & IL & 27.0 & $43: 22$ & $3 / 26$ & (9) & $12: 53$ \\
\hline 180.0 & 124 & & INGLEWOOD & $w$ & $\mathrm{I} 24$ & 165 & TN & 2307.0 & $47: 08$ & $3 / 26$ & (a) & $16: 39$ \\
\hline 5.0 & $I 24$ & 165 & NASHVILLE & SE & 124 & 140 & $\mathrm{TN}$ & 2312.0 & $47: 14$ & $3 / 26$ & (3) & $16: 45$ \\
\hline 2.0 & 124 & 140 & NASHVILLE & $\mathrm{E}$ & I 24 & $\mathrm{I} 40$ & TN & 2314.0 & $47: 17$ & $3 / 26$ & (3) & $16: 48$ \\
\hline 134.0 & 124 & & EAST RIDGE & NE & $I 24$ & I75 & $\mathrm{TN}$ & 2448.0 & $50: 13$ & $3 / 26$ & (9) & $20: 44$ \\
\hline 93.0 & $I 75$ & & ATLANTA & NW & I285 & 175 & GA & 2541.0 & $51: 55$ & $3 / 26$ & (a) & $22: 26$ \\
\hline 25.0 & I285 & & ATLANTA & $\mathbf{E}$ & 120 & I285 & $\mathrm{GA}$ & 2566.0 & $52: 23$ & $3 / 26$ & () & $22: 53$ \\
\hline 138.0 & 120 & & NORTH AUGUSTA & NW & I 20 & $\$ 230$ & sc & 2704.0 & $55: 23$ & $3 / 27$ & $@$ & $1: 54$ \\
\hline 3.0 & $\$ 230$ & & NORTH AUGUSTA & & & & $\mathrm{sC}$ & 2707.0 & $55: 29$ & $3 / 27$ & (1) & $1: 59$ \\
\hline 2.0 & $\$ 125$ & & CLEARWATER & W & U1. & U278 & $\mathrm{sc}$ & 2709.0 & $55: 33$ & $3 / 27$ & (-) & $2: 04$ \\
\hline 5.0 & $\mathrm{U} 278$ & & BEECH ISLAND & & U278 & $\$ 125$ & sc & 2714.0 & $55: 39$ & $3 / 27$ & $\Theta$ & $2: 09$ \\
\hline 11.0 & $\mathrm{~S} 125$ & & JACKSON & SE & $S 125$ & LSRP & sc & 2725.0 & $55: 52$ & $3 / 27$ & (1) & $2: 22$ \\
\hline 3.0 & LSRP & & SRL & & & & sc & 2728.0 & $55: 58$ & $3 / 27$ & (a) & $2: 29$ \\
\hline
\end{tabular}


HNF-1840, Rev. 0

\section{Table 1, cont.}

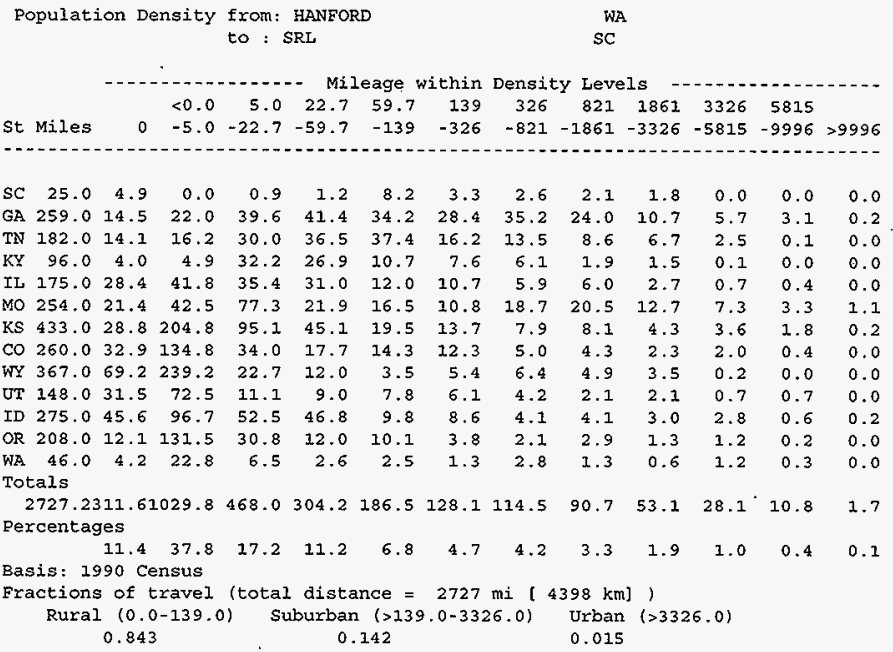

End of route. 
HNF-1840, Rev. 0

Table 2. Hanford to SRS rail route data. (source: INTERLINE routing model [Johnson et al. 1993b])

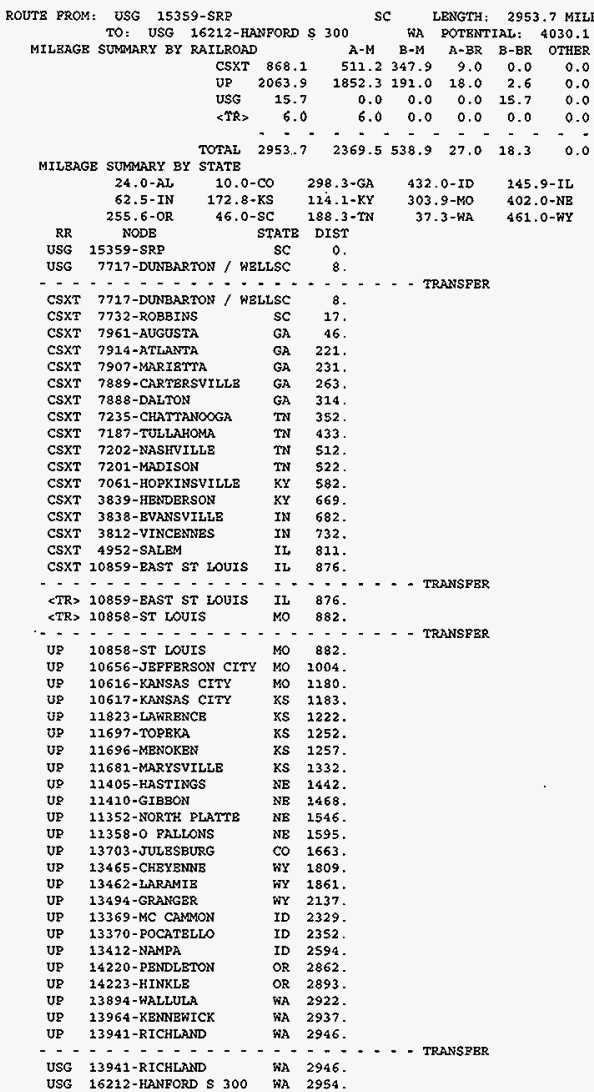


HNF-1840, Rev. 0

Table 2, cont.

POPULATION DENSITY FROM: USG 15359-SRP SC

TO: USG 16212-HANFORD $\$ 300$ WA

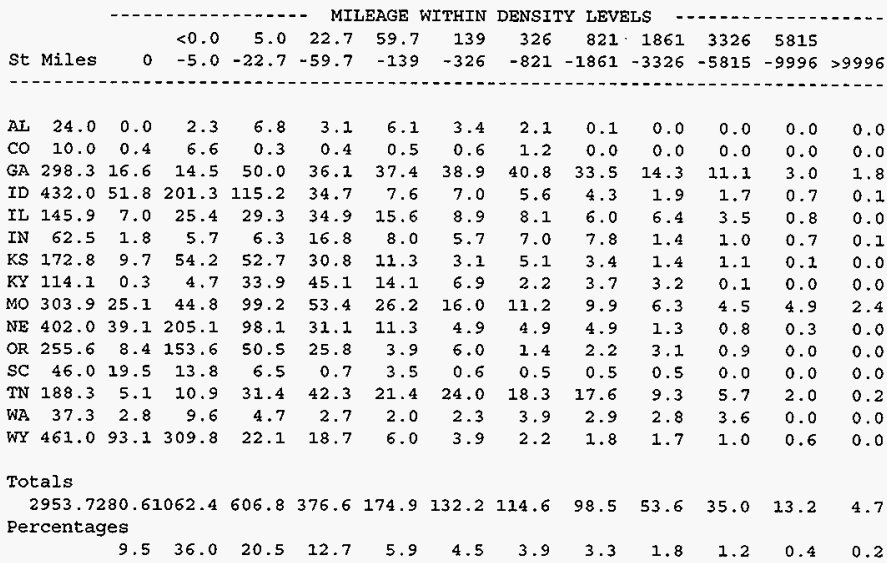

RADTRAN Input Data

Rural Suburban Uxban

Weighted Population

People/sq. mi.

People/sq. $\mathrm{km}$.

$\begin{array}{rrr}17.6 & 921.5 & 5884.3 \\ 6.8 & 355.8 & 2271.9\end{array}$

Distance

Miles

Kilometers

Percentage

$\begin{array}{rrrr}2501.3 & 398.9 & 52.9 & 2953.7 \\ 4025.4 & 641.9 & 85.1 & 4753.4 \\ 84.7 & 13.5 & 1.8 & \end{array}$

Basis (people/sq. mi.) $<139139-3326>3326$

Note: Due to rounding, the sum of the mileages in the individual population categoxies may not equal the total mileage shown on this report. 
HNF-1840, Rev. 0

Table 3. Accident occurrence and fatality rates for the states traversed by the Hanford to SRS highway and rail routes (source: Saricks and Kvitek 1994).

\begin{tabular}{|c|c|c|c|c|c|c|c|}
\hline & \multicolumn{3}{|c|}{$\begin{array}{l}\text { Truck Accident Rate } \\
\text { accidents } / \mathrm{km}\end{array}$} & \multicolumn{3}{|c|}{$\begin{array}{l}\text { Truck ratality Rate } \\
\text { fatalities/km }\end{array}$} & \multirow{2}{*}{$\begin{array}{l}\text { Rail Accident } \\
\text { Rate } \\
\text { accidents } / \mathrm{km}\end{array}$} \\
\hline & rural & suburb & urban & rural & suburb & urban & \\
\hline AL & $N A^{2}$ & $\mathrm{NA}$ & $\mathrm{NA}$ & $\mathrm{NA}$ & $\mathrm{NA}$ & NA & $4.80 E-08$ \\
\hline $\mathrm{CO}$ & $2.76 \mathrm{E}-07$ & $4.52 \mathrm{E}-07$ & $6.28 \mathrm{E}-07$ & $2.45 E-08$ & $2.92 \mathrm{E}-08$ & $3.38 \mathrm{E}-08$ & $1.73 \mathrm{E}-08$ \\
\hline GA & $1.65 \mathrm{E}-07$ & $3.26 \mathrm{E}-07$ & $4.87 \mathrm{E}-0 ?$ & $1.86 \mathrm{E}-08$ & $2.12 \mathrm{E}-0$. & $2.37 \varepsilon-08$ & $6.44 \mathrm{E}-08$ \\
\hline ID & $2.30 \mathrm{E}-07$ & $2.02 \mathrm{E}-07$ & $1.73 \mathrm{E}-07$ & $2.06 \varepsilon-08$ & $1.03 \mathrm{E}-08$ & $0.00 E+00$ & $7.01 \mathrm{E}-08$ \\
\hline IL & $1.76 \mathrm{E}-07$ & $5.26 \mathrm{E}-07$ & $8.75 E-07$ & $1.39 \varepsilon-08$ & $3.368-08$ & $5.33 E-08$ & $1.07 E-07$ \\
\hline IN & NA & NA & NA & NA & NA & $\mathrm{NA}$ & $4.64 \varepsilon-08$ \\
\hline ks & $2.04 E-07$ & $3.26 \mathrm{E}-07$ & $4.48 E-07$ & $1.88 \mathrm{E}-08$ & $3.70 \mathrm{E}-08$ & $5.52 \mathrm{E}-08$ & 3. $61 \mathrm{E}-08$ \\
\hline KY & $1.46 \varepsilon-07$ & $3.30 \mathrm{E}-07$ & $5.13 E-0 ?$ & $1.50 \mathrm{E}-08$ & $2.36 \mathrm{E}-08$ & $3.22 \mathrm{E}-08$ & $4.48 E-08$ \\
\hline Mo & $1.78 \mathrm{E}-07$ & $3.48 \mathrm{E}-07$ & $5.18 \mathrm{E}-07$ & 1.23E-08 & $2.77 \mathrm{E}-08$ & 4. $30 \mathrm{E}-08$ & $5.28 \mathrm{E}-08$ \\
\hline NE & NA & $\mathrm{NA}$ & $\mathrm{NA}$ & $\mathrm{NA}$ & $\mathrm{NA}$ & $\mathrm{NA}$ & $4.63 \mathrm{E}-08$ \\
\hline OR & $2.20 \mathrm{E}-07$ & $3.10 \mathrm{E}-07$ & $3.99 \mathrm{E}-07$ & $1.12 E-08$ & $1.80 \mathrm{E}-08$ & $2.47 \mathrm{E}-08$ & 1. $25 \mathrm{E}-07$ \\
\hline $\mathrm{sc}$ & $1.83 \mathrm{E}-07$ & $2.48 E-07$ & $3.13 E-07$ & $2.57 E-08$ & $2.73 \mathrm{E}-08$ & $2.88 \mathrm{E}-08$ & $5.11 \mathrm{E}-08$ \\
\hline $\mathrm{TN}$ & 1. $48 \mathrm{E}-07$ & 4. $73 E-07$ & $7.97 \mathrm{E}-07$ & $1.63 \mathrm{E}-08$ & $3.61 \mathrm{E}-08$ & $5.59 \mathrm{E}-08$ & $5.59 \mathrm{E}-08$ \\
\hline UT & $2.41 \mathrm{E}-07$ & $2.47 \mathrm{E}-07$ & $2.52 \mathrm{E}-07$ & $2.21 \mathrm{E}-08$ & $1.408-08$ & $5.90 \mathrm{E}-09$ & NA \\
\hline $\mathrm{HA}$ & $2.50 E-07$ & $2.068-07$ & $1.61 E-07$ & $1.47 \mathrm{E}-08$ & $1.14 E-08$ & $8.00 \mathrm{e}-09$ & $3.49 \mathrm{E}-08$ \\
\hline$w Y$ & $3.42 \mathrm{E}-07$ & $3.20 \mathrm{E}-07$ & $2.98 \mathrm{E}-07$ & $2.08 E-08$ & $3.04 \mathrm{E}-08$ & $0.00 \mathrm{E}+00$ & $3.10 E-08$ \\
\hline us & $2.03 \mathrm{E}-07$ & $2.81 \mathrm{E}-07$ & $3.58 \mathrm{E}-07$ & $1.91 E-08$ & $2.14 \mathrm{E}-08$ & $2.37 \varepsilon-08$ & $5.57 \mathrm{E}-08$ \\
\hline
\end{tabular}

${ }^{a} \mathrm{NA}=$ route does not traverse that particular state.

Table 4. Accident Severity Category Conditional Probabilities (source: Adapted from Fischer et al. 1987)

\begin{tabular}{|lcc|}
\hline & Conditional Probability by Severity Category \\
Zone & 1 & 2 \\
Rural & 0.994 & 0.006 \\
Suburban & 0.994 & 0.006 \\
Urban & 0.994 & 0.006 \\
\hline
\end{tabular}

Table 5. Accident Release Fractions by Severity Category

Nuclide

Release Fraction by Severity Category

$\mathrm{H}-3$

$\begin{array}{cc}1 & 2 \\ 0 & 0.008 \\ 0 & 5.0 \mathrm{E}-08\end{array}$


Table 6. Summary of General RADTRAN Input Parameters

\begin{tabular}{|lrr||}
\hline \multicolumn{1}{|c}{ Parameter } & \multicolumn{1}{c}{ Truck } & \multicolumn{2}{c|}{ Rail } \\
\hline Package type & Type B cask & Type B Cask \\
No. of crewmen & 2 & 5 \\
External dose rate $(\mathrm{mrem} / \mathrm{hr} @ 2 \mathrm{~m})$ & 10 & 10 \\
Distance from source to crew $(\mathrm{m})$ & 3 & 152 \\
Average vehicular speed $(\mathrm{km} / \mathrm{h})$ & & \\
Rural & 88 & 64 \\
Suburban & 40 & 40 \\
Urban & 24 & 24 \\
Stop time $(\mathrm{h} / \mathrm{km})$ & 0.011 & 0.033 \\
No. of people exposed while stopped & 25 & 100 \\
No. of people per vehicle sharing & 2 & 3 \\
route & & \\
Population densities (persons $\left./ \mathrm{km}{ }^{2}\right)$ & route-specific & route-specific \\
& & \\
One-way traffic count $($ vehicles $/ \mathrm{h})$ & & 5 \\
Rural & & \\
Suburban & & \\
Urban & & \\
\hline
\end{tabular}

${ }^{a}$ Route-specific population densities were used for the RADTRAN accident risk assessment. For the maximum accident consequence assessment, densities of 7 ; 800; and 1,900 persons $/ \mathrm{km}^{2}$ were used for rural, suburban, and urban areas, respectively.

Source: Neuhauser and Kanipe 1993. 
HNF-1840, Rev. 0

Table 7. Summary of Annual Shipment Information and Collective Population Impacts

\begin{tabular}{|c|c|c|c|c|}
\hline \multirow[b]{2}{*}{ Parameter } & \multicolumn{2}{|c|}{ Truck Shipments } & \multicolumn{2}{|c|}{ Rail Shipments } \\
\hline & Scenario 1 & Scenario 2 & Scenario 1 & Scenario 2 \\
\hline \multicolumn{5}{|l|}{ Shipment summary } \\
\hline Annual Number of Cask Shipments & 4 & 18 & 4 & 18 \\
\hline H-3 Inventory ( $\mathrm{Ci} /$ shipment) & $10 \mathrm{MCi}$ & $2 \mathrm{MCi}$ & $10 \mathrm{MCi}$ & $2 \mathrm{MCi}$ \\
\hline Route distance (one-way mi) & 2,728 & 2,728 & 2,954 & 2,954 \\
\hline Total Mileage (one-way $\mathrm{mi} / \mathrm{yr}$ ) & 10,900 & 49,100 & 11,800 & 53,200 \\
\hline \multicolumn{5}{|l|}{ Population impacts } \\
\hline \multicolumn{5}{|l|}{ Cargo-related impacts ${ }^{a}$} \\
\hline \multicolumn{5}{|l|}{ Annual Dose Risk (person-rem) } \\
\hline Routine crew & 0.97 & 4.35 & 0.85 & 3.8 \\
\hline Routine public & 1.24 & 5.6 & 0.17 & 0.76 \\
\hline Accident & 0.002 & 0.002 & 0.0002 & 0.0002 \\
\hline \multicolumn{5}{|l|}{ Latent cancer fatalities $b$} \\
\hline Crew fatalities & $4 \times 10^{-4}$ & $2 \times 10^{-3}$ & $3 \times 10^{-4}$ & $2 \times 10^{-3}$ \\
\hline Public fatalities & $6 \times 10^{-4}$ & $3 \times 10^{-3}$ & $8 \times 10^{-5}$ & $4 \times 10^{-4}$ \\
\hline \multicolumn{5}{|l|}{ Vehicle-related impacts $\mathrm{c}$} \\
\hline Emission fatalities & $5 \times 10^{-5}$ & $2 \times 10^{-4}$ & $9 \times 10^{-5}$ & $4 \times 10^{-4}$ \\
\hline Traffic accident fatalities & $7 \times 10^{-4}$ & $3 \times 10^{-3}$ & $3 \times 10^{-5}$ & $1 \times 10^{-4}$ \\
\hline
\end{tabular}

a Cargo-related impacts are those impacts attributable to the radioactive nature of the material.

${ }^{b}$ Latent cancer fatalities are calculated by multiplying dose by the ICRP publication 60

(ICRP 1991) health risk conversion factors of $4 \times 10^{-4}$ and $5 \times 10^{-4}$ fatal cancers per person-rem for workers and for the public, respectively.

c Vehicle-related impacts are those impacts that are independent of the cargo in the shipment. 
Table 8. Impacts to Maximally Exposed Individuals During Routine Transportation Conditions $^{\mathrm{a}}$

\begin{tabular}{|c|c|c|c|c|}
\hline & \multicolumn{2}{|c|}{ Dose (rem/event) } & \multicolumn{2}{|c|}{ Lifetime Risk ${ }^{c}$} \\
\hline Receptor $b$ & Truck & Rail & Truck & Rail \\
\hline \multicolumn{5}{|l|}{ Workers } \\
\hline Crew member & d & $d$ & d & $\mathrm{d}$ \\
\hline Inspector & 0.0029 & 0.0029 & $1 \times 10^{-6}$ & $1 \times 10^{-6}$ \\
\hline Rail inspector & NA & 0.0013 & $\mathrm{NA}$ & $5 \times 10^{-7}$ \\
\hline \multicolumn{5}{|l|}{ Public } \\
\hline Resident & $4.0 \times 10^{-7}$ & $4.0 \times 10^{-7}$ & $2 \times 10^{-10}$ & $2 \times 10^{-10}$ \\
\hline Person in traffic jam & 0.011 & 0.011 & $6 \times 10^{-6}$ & $6 \times 10^{-6}$ \\
\hline Person at service station & $3.1 \times 10^{-4}$ & NA & $2 \times 10^{-7}$ & NA \\
\hline Resident near rail stop & NA & $1.3 \times 10^{-5}$ & NA & $7 \times 10^{-9}$ \\
\hline
\end{tabular}

${ }^{\text {aT }}$ The external dose rate is assumed to be $10 \mathrm{mrem} / \mathrm{h}$ at $2 \mathrm{~m}(6.6 \mathrm{ft})$ for all shipments.

${ }^{\mathrm{b}}$ Receptor assumptions are described in the text.

${ }^{c}$ Lifetime risk of fatal cancer based on ICRP publication 60 (ICRP 1991) health risk conversion factors of $4 \times 10^{-4}$ and $5 \times 10^{-4}$ fatal cancers per person-rem for workers and members of the public, respectively.

d The DOE administrative control level limits doses to DOE workers to 2 rem/yr. 
HNF-1840, Rev, 0

Table 9. Summary of the Maximum Accident Consequence Assessment - Population Impacts for Rural, Suburban, and Urban Areas Under Neutral and Stable Weather Conditions $^{\mathrm{a}}$

\begin{tabular}{|c|c|c|c|c|}
\hline \multirow[b]{2}{*}{$\begin{array}{l}\text { Accident } \\
\text { Location }\end{array}$} & \multicolumn{2}{|c|}{ Scenario 1} & \multicolumn{2}{|c|}{ Scenario 2} \\
\hline & $\begin{array}{l}\text { Population Dose } \\
\text { (person-rem) }\end{array}$ & $\begin{array}{l}\text { Health Effects } \\
\text { (cancer fatalities) }\end{array}$ & $\begin{array}{l}\text { Population Dose } \\
\text { (person-rem) }\end{array}$ & $\begin{array}{l}\text { Health Effects } \\
\text { (cancer fatalities) }\end{array}$ \\
\hline & & Neutral Weather Conditions ${ }^{\mathrm{b}}$ & & \\
\hline Urban & 148 & $7 \times 10^{-2}$ & 30 & $1 \times 10^{-2}$ \\
\hline Suburban & 62 & $3 \times 10^{-2}$ & 12 & $6 \times 10^{-3}$ \\
\hline Rural & 0.55 & $3 \times 10^{-4}$ & 0.11 & $6 \times 10^{-5}$ \\
\hline & & Stable Weather Conditions ${ }^{\mathfrak{c}}$ & & \\
\hline Urban & 217 & $1 \times 10^{-1}$ & 43 & $2 \times 10^{-2}$ \\
\hline Suburban & 92 & $5 \times 10^{-2}$ & 18 & $1 \times 10^{-2}$ \\
\hline Rural & 0.80 & $4 \times 10^{-4}$ & 0.16 & $8 \times 10^{-5}$ \\
\hline
\end{tabular}

${ }^{2}$ The consequences presented are for the most severe credible truck accidents, corresponding to a release of $0.8 \%$ of the total tritium inventory. Populations extend at a uniform population density to a radius of $80 \mathrm{~km}(50 \mathrm{mi})$ from the accident site. Population exposure pathways include acute inhalation; acute cloudshine; groundshine; resuspended inhalation; resuspended cloudshine; and ingestion of food, including initially contaminated food (rural only). No decontamination or mitigative actions are taken.

${ }^{b}$ Neutral weather conditions result in moderate dispersion and dilution of the released plume. Neutral conditions were taken to be Pasquill stability Class $D$ with a wind speed of $4 \mathrm{~m} / \mathrm{s}(9 \mathrm{mi} / \mathrm{h})$. Neutral conditions occur approximately 50 percent of the time in the United States.

c Stable weather conditions result in minimal dispersion and dilution of the released plume and are thus unfavorable. Stable conditions were taken to be Pasquill stability Class F with a wind speed of $1 \mathrm{~m} / \mathrm{s}(2.2 \mathrm{mi} / \mathrm{h})$. Stable conditions occur approximately one-third of the time in the United States. 


\section{REFERENCES}

Fischer, L.E., C.K. Chou, M.A. Gerhard, C.Y. Kimura, R.W. Martin, R.W. Mensing, M.E. Mount, and M.C. Wette, 1987, Shipping Container Response to Severe Highway and Railway Accident Conditions, NUREG/CR-4829, UCID-20733, prepared by Lawrence Livermore National Laboratory for Office of Nuclear Regulatory Research, U.S. Nuclear Regulatory Commission, Washington, D.C.

International Commission on Radiological Protection (ICRP). 1990 Recommendations of the International Commission on Radiological Protection. ICRP Publication 60. Annals of the ICRP. Vol. 21. No. 1-3. New York: Pergamon Press, 1991.

Johnson, P. E., D. S. Joy, D. B. Clark, and J. M. Jacobi, 1993a. HIGHWAY 3.1, An Enhanced Transportation Routing Model: Program Description, Methodology, and Revised User's Manual. ORNL/TM-12124. Oak Ridge National Laboratory. Oak Ridge, TN. March.

Johnson, P.E., D.S. Joy, D.B. Clark, and J.M. Jacobi. 1993b. INTERLINE 5.0, An Expanded Railroad Routing Model: Program Description, Methodology, and Revised User's Manual. ORNL/TM-12090. Oak Ridge, TN: Oak Ridge National Laboratory. March.

Nielsen, D., 1997, "FFTF Tritium Target Transportation Scenarios," memorandum from D. Nielsen to Fred Monette (Argonne National Laboratory), August 12.

Neuhauser, K. S., and F. L. Kanipe. RADTRAN 4 User Guide. SAND89-2370. Sandia National Laboratories, Albuquerque, N.M. January 1992.

Rao, R.K., E.L. Wilmot, and R.E. Luna. 1982. Non-Radiological Impacts of Transporting Radioactive Material. SAND81-1703. TTC-0236. Albuquerque, NM: Sandia National Laboratories.

Saricks, C, and T. Kvitek. 1994. Longitudinal Review of State-Level Accident Statistics for Carriers of Interstate Freight. ANL/ESD/TM-68. Argonne, IL: Argonne National Laboratory. March.

U.S. Department of Energy, 1997, Final Waste Management Programmatic Environmental Impact Statement for Managing Treatment, Storage, and Disposal of Radioactive and Hazardous Waste, DOE/EIS-0200-F, Office of Environmental Management, Washington, D.C., May.

U.S. Department of Energy, 1996, Final Environmental Impact Statement on a Proposed 
Nuclear Weapons Nonproliferation Policy Concerning Foreign Research Reactor Spent Nuclear Fuel, DOE/EIS-0218F, Office of Environmental Management, Washington, D.C., February.

U.S. Department of Energy, 1995, Programmatic Spent Nuclear Fuel Management and Idaho National Engineering Laboratory Environmental Restoration and Waste Management Programs Final Environmental Impact, DOE/EIS-0203-F, Office of Environmental Management, Washington, D.C., April.

Yuan, Y. C., et. al., 1995. RISKIND - A Computer Program for Calculating Radiological Consequences and Health Risks from Transportation of Spent Nuclear Fuel. ANL/EAD-1. Argonne National Laboratory, Argonne, I1l. November. 


\section{DISTRIBUTION SHEET}

\begin{tabular}{l|l|l|l|l|l}
\hline To & \multicolumn{2}{l|}{$\begin{array}{l}\text { From } \\
\text { Distribution }\end{array}$} & $\begin{array}{l}\text { Pacific Northwest Laboratory } \\
\text { K. Rhoades }\end{array}$ & Page 1 of 1 \\
\cline { 3 - 5 } & Date $11 / 18 / 97$ \\
\hline Project Title/Work Order & Health and Safety Consequences of Medical Isotope Processing at \\
the Hanford Site 325 Building & ECN No. N/A \\
\hline \multicolumn{2}{c|}{ Name } & MSIN & $\begin{array}{c}\text { Text } \\
\text { With All } \\
\text { Attach. }\end{array}$ & $\begin{array}{c}\text { Text Only } \\
\begin{array}{c}\text { Attach./ } \\
\text { Appendix } \\
\text { Only }\end{array}\end{array}$ & $\begin{array}{c}\text { EDT/ECN } \\
\text { Only }\end{array}$ \\
\hline
\end{tabular}

B\&W Llanford Company
J. D. Briggs
T. M. Burke
S. Guttenberg
G3-42
N2-01
N2 -53
S. W. Hiller
D. M. Lucoff
N2-02
N2-01
N2-53
N2-57
N2-11
N2-57
J. N. Paglieri
J. E. Parker
N2-57

$x$
$x$
$x$
$x$
$x$
$x$
$x$
$x$
$x$
$x$
P. R. Prevo
R. 0 . Zimmerman
$-x$

Pacific Northwest Nationa] Laboratory

W. T. Farris

C. S. Glantz

D. E. Lucas

K. Rhoades

L. H. Staven

T. S. Tenforde

Central Files

Station 22 (EDT, SD Cover only)
$\mathrm{H} 5-31$

$\mathrm{K} 6-80$

$\mathrm{K} 3-66$

K3-54

$\mathrm{K} 3-54$

P7 -52

B1-07 $X$

N2-12
$X$
$X$
$X$
$X$
$X$
$X$ 